\title{
How America disguises its violence: colonialism, mass incarceration, and the need for resistant imagination
}

\author{
Shari Stone-Mediatore \\ Ohio Wesleyan University, Delaware, $\mathrm{OH}$, USA
}

\begin{abstract}
This paper examines how adelusive social imaginary of criminal-justice has underpinned contemporary U.S. mass incarceration and encouraged widespread indifference to its violence. I trace the complicity of this criminal-justice imaginary with state-organized violence by comparing it to an imaginary that supported colonial violence. I conclude by discussing how those of us outside of prison can begin to resist the entrenched images and institutions of mass incarceration by engaging the work and imagining the perspective of incarcerated people.
\end{abstract}

KEYWORDS Colonialism; criminalization; mass incarceration; prison; ; standpoint theory

We Americans have perfected the art of being both sanctimonious and deliberately indifferent to the plight of others.

Joseph Dole, 'Abolish long-term solitary confinement'

For many Americans, state-organised violence is a problem for other countries but not our own. America is imagined to be ruled by law, which is viewed as a counterforce to violence and brutality. And yet, as part of its criminal-legal system, the United States currently incarcerates a greater percentage of its citizens than any other nation. The 2 million individuals held in prisons and jails across the country have little protection against rampant physical, sexual, and psychological abuse in facilities that operate with little public oversight.Nearly 200,000 men and women are sentenced to spend their entire lives behind bars, many for convictions as juveniles or young adults. Over 80,000 individuals are confined to solitary units, where they spend 23 to 24 hours a day alone in cells no larger than 8 by 10 feet, sometimes for years or even decades, in conditions that the United Nations considers torture (ACLU, 2011, Everest, 2013, Mayeux 2015, Rovner, 2016, Ghandnoosh, 2017, Solitary Watch, n.d., The Sentencing Project, n.d.). 
This paper brings critical attention to the violence of mass incarceration by examining how it has been masked and facilitated by adelusive social imaginary of criminal justice. I sketch this imaginary's contours by comparing it to an imaginary underpinning colonialism. This investigation accords with recent work by critical race theorists, who have traced continuities between mass incarceration and systems of racialised violence, forced labor, and legal inequality that constituted U.S. slavery (Alexander 2011, Dilts, 2014, Peláez, 2016). However, while much of the literature views mass incarceration in the context of slavery, I draw on recent scholars of colonialism, including Dussel (1995), Quijano (2000), and Rodriguez (2014, 2015)), to trace recurring colonialist patterns of state-violence-disguised-as-righteousness. Colonialism is not the only form of institutionalised violence that reverberates in mass incarceration; however, recent studies of colonialism offer particularly illuminating insight into the cultural processes that allow 'civilised' people to accept and even exalt barbaric violence.

In tracing analogies between a colonial imaginary of righteous violence and a contemporary criminal-justice imaginary, I elucidate several mechanisms that disguise and support the violence of mass incarceration. I conclude by examining how the faculty of imagination can help destabilise these mechanisms and contribute to honest and responsible engagement with the U.S. criminal-legal system. I argue that, while empirical documentation of the violence of mass incarceration is crucial, we can resist the hold of an imaginary that abets high-minded indifference only when those of us outside prison walls begin to imagine the perspective of those held within. ${ }^{1}$

\section{Colonialism and the disguising of violence}

Critics describe colonialism primarily as a vast system of violence. In his classic study of European colonialism, Frantz Fanon argued that 'the conquest of a national territory and the oppression of a people' that constitute colonialism could be achieved only with multi-pronged and systemic violence (1967, p. 81). 'The colonialist structure,' Fanon stressed, 'rests on the necessity of torturing, raping, and committing massacres' as well as imposing European values and customs through 'cannons and sabers,' to maintain the 'through and through' subjugation of the colonised people (1967, pp. $34,40,72$ ). Aimé Césaire confirms that colonial rule was maintained only by extreme brutality, including mutilation, massacres of whole cities, forcible transport of millions of men to labour camps, burning of homes, land-theft, and cultural destruction (1972, pp. 18-22).

Colonialism in the Americas was equally violent. The Spanish conquistadores pillaged 185,000 kilograms of gold and 16,000,000 kilograms of silver while killing millions of indigenous Americans through military aggression, land-theft, famine, rape, forced labour, and deprivation-exacerbated 
diseases (Dussel, 1995, pp. 38-45, Todorov, 1984, pp. 132-42). Colonisers sabotaged indigenous knowledge-production (Quijano, 2000, p. 541, Rodriguez, 2014). They also inflicted sexual violence on indigenous women, using women's bodies to disempower indigenous men and destroy the social fabric (Dussel, 1995, pp. 45-47, Smith, 2005, pp. 15-33).

\section{A colonial imaginary of righteous violence}

As scholars of colonialism show, colonial institutions could be maintained only through an ensemble of coercive military, socio-political, and cultural mechanisms. I focus here on one component of this machinery: a social imaginary that allowed Europeans to interpret colonialism as a noble endeavour. European politicians and intellectuals alike presented colonialism in various kinds of edifying rhetoric; it was presented as salvation for savages, a civilizing mission, a gifting of material progress, and a productive use of idle land (Césaire 1972, pp. 13-22, Dussel, 1995, pp. 64-71). Walter Mignolo describes the basic ruse by which colonial brutality was refashioned in noble clothes as the logic of coloniality. This logic appears, Mignolo says, whenever 'control, domination, and exploitation' are cloaked 'in the language of salvation, progress, modernization, and being good for everyone' (2005, p. 6). If this logic made sense to ordinary Europeans, however, it is because the logic was animated by what I call an imaginary of righteous violence: a set of culturally transmitted myths of social identities and the social world that allowed Europeans to make sense of the outrageous claim that colonialism was 'for the good of all' (Juan Ginés de Sepúlveda cited Dussel, 1995, p. 63). Below, I describe how key elements of the colonial imaginary sustained this deception.

\section{'The Indian' as violable subject}

'Indian,' of course, was the name that Columbus gave to the inhabitants of the western Atlantic islands, which he thought was India. From the beginning, the European image of 'the Indian' was developed - not through close attention to, or communicative interaction with, indigenous people - but through colonisers imposing their perspective and interests on the people whose land they occupied. As ruling-class Europeans sought to present themselves as authoritative knowers, rightful settlers, and world rulers, 'Indians' were invented as people who had no culture, no diligence, no laws, no morals, and no reason; in effect, creatures whom Europeans could dominate and exploit while attributing their aggression to the subjugated people's 'vices'.

Colonial-era scholars betray the European interests behind the construction of 'the Indian.' For instance, while Spain was invading the Americas, the Spanish philosopher Juan Ginés de Sepúlveda argued in his famous 
Valladolid debate with Bartolomé de Las Casas that 'the Indian' was naturally servile and Spaniards naturally suited to rule (Todorov, 1984, p. 153). As Western European nations began to appropriate American land, the lazy and unruly 'Indian' served as a foil for the supposedly disciplined and productive (male, upper-class) European. For instance, in the mid-1 $7^{\text {th }}$ century, Thomas Hobbes $(1968$, p. 187) contrasted his proposed law-based government to the 'brutish' conditions of 'the savage people' in the Americas. Half a century later, John Locke $(1980, \mathrm{pp} .21,24)$ contrasted 'the industrious and rational' landholders of England to both 'the quarrelsome and contentious' people living on the English commons and 'the needy and wretched' people of the Americas, both of whom were supposedly unfit for land ownership. In the $19^{\text {th }}$ century, Georg Wilhelm Hegel contrasted the strong-spirited people of 'the West' to 'the Indians' of South America, who were supposedly so slothful that 'at midnight a bell had to remind them even of their matrimonial duties' (1956, p. 82).

\section{'Progress' as 'good for all'}

If 'the Indian' represented an innately defective subject whose vices justified the violence inflicted on him, then invocations of higher ideals allowed the violence to be lauded as noble. Early colonisers claimed to bring 'civilisation' to 'savages.' Later colonisers increasingly appealed to socio-economic ideals of 'progress' and 'modernisation.' In all its permutations, the idealised form of life was conceived from a European perspective but presented as universal. 'Progress,' for instance, was cast in European liberal-capitalist terms but regarded as the supreme aim of all human communities (Césaire 1972, pp. 11-17, Dussel, 1995, pp. 64-67).

Eurocentric images of 'progress' compounded a myth of human advancement that found expression in thinkers from Hobbes to Hegel. In this myth, 'progress' was construed as 'a trajectory that departed from a state of nature and culminated in Europe' (Quijano, 2000, p. 542). Even when the $19^{\text {th }}$ century brought greater attention to history, the same basic myth of the West as the apex of humanity became further elaborated. For instance, Hegel $(1956$, p. 99) claimed that Africans were so incapable of development that their enslavement by Europeans constituted 'a phase of education' by 'a higher morality and the culture connected with it.' Ultimately, images of 'progress' and 'the Indian' did not so much deny colonial violence as cast it as 'pedagogic violence,' for which colonisers considered themselves 'not only innocent, but meritorious for inflicting' (Dussel, 1995, p. 66).

\section{The colonial imaginary and the institutionalising of violence}

The colonial imaginary not only dressed colonial violence in edifying clothes but provided visions for organising colonial institutions. In particular, images 
of 'the backward Indian' and 'the modern Westerner' gave force to the modern logic of 'race,' around which colonial society was organised. 'Race' logic both organised colonial hierarchies and disguised them as a function of 'natural (racial) differences and not consequences of a history of power' (Quijano, 2000, p. 541). In effect, as 'race' differences were codified in law and materialised in divisions of labour, colonial hierarchies gained a veneer of normalcy. The racially organised society 'confirmed' that indigenous people were unfit for the polity and 'naturally obliged to work for the profit' of Europeans (Quijano, 2000, p. 539).

The imaginary of righteous violence also demanded violent tactics to maintain its own credibility. Since the Conquest, indigenous people have resisted European cultural hegemony and continued to live by their own values and narratives (Rodriguez, 2014). Thus, European colonizers could maintain the presumed universality of their cultural frameworks only by force. The early conquistadores tore down temples, set fire to eight centuries of Mayan codices, and burned alive indigenous spiritual leaders (Dussel, 1995, pp. 42-54, Quijano, 2000, pp. 540-542, Rodriguez, 2014, pp. 28-37). In the 19th and 20th centuries, the U.S. and Canadian governments outlawed Native American spiritual practices and forced Native American children into boarding schools, where their languages and rituals were forbidden (Smith, 2005, pp. 35-53). More recently, in continued efforts to suppress challenges to colonialist interpretations of the world, the Arizona state legislature has outlawed popular Raza Studies programs in Tucson, fired teachers, and banned books (Rodriguez, 2015).

\section{The colonial imaginary and the thwarted imagination}

Finally, colonialist myths discouraged Europeans from imagining colonialism from the standpoint of indigenous Americans. The philosopher Hannah Arendt explained the role that the faculty of imagination plays in our understanding of political phenomena. Following Kant, Arendt explained that the imagination is 'an important tool of cognition' by which we represent to ourselves in our mind a phenomenon that is not directly present (Arendt, 1953a, p. 79). Arendt's insight is that the imagination is especially vital to political thinking. This is because political phenomena cannot be reduced to preconceived categories or logics but can be adequately understood only when approached as humanly initiated and humanly endured phenomena that appear under 'innumerable perspectives and aspects' (Arendt, 1958, p. 57). With the imagination, Arendt explained, we can approach a political phenomenon in its uniqueness and existential richness, even while exceeding our immediate experience of that phenomenon; for we can imaginatively 'visit' the standpoint of others and thereby engage the phenomenon in its human depth but from new angles (1953b, pp. 391-392, 1982, p. 43). In effect: If a social imaginary guides us in making sense of the 
world in terms of received cultural logics, then the imagination (as a faculty) keeps us responsive to aspects of the living world that exceed familiar llogics.

Feminist critics have raised questions about the adequacy of the imagination for engaging radical otherness. For instance, how can we ensure that our imaginative 'visiting' of another's standpoint is true to the other's very different way of seeing the world? How do we ensure that we do not bring so much baggage on our 'visit' that our own biases burden our imagination of the other's perspective? In light of such concerns, feminist scholars have emphasized the need for interaction and solidarity with concrete others, or close engagement with others' stories, which can be challenging and discomfiting (Ortega, 2006, Stone-Mediatore, 2003, pp. 74-78, Taylor, 1993). Still, these concerns do not so much devalue the imagination as they underscore the need to pursue imaginative 'visiting' with humility, diligence, and attentiveness to concrete others.

In the context of colonialism, the myth of 'the Indian' thwarted precisely the kind of work necessary for Europeans to imagine indigenous perspectives with any adequacy. Granted, many Europeans had political, economic, and psychological interests that deterred them from considering indigenous perspectives. Still, the myth of 'the Indian' abetted such self-interested myopia by suggesting that the indigenous people had no perspective of their own for Europeans to consider. As Dussel put it (1995, p. 33), 'the Indian' was an 'aesthetic and contemplative fantasy' of Europeans that 'covered over' actual indigenous people with an image of Europe's projection. Moreover, the myth of 'the backward Indian' boosted European attitudes of superiority and authority, thereby derailing precisely the kind of humility and listening skills that would have been necessary for meaningful 'visiting' of indigenous standpoints. In effect, the myth facilitated a situation in which colonisers did not try to learn the indigenous people's language, listen to them, or understand their cultures but viewed the indigenous people as mere objects to analyse or bodies to exploit. '[l]n the best of cases,' says Todorov, referring to the Spaniards' fascination with the Aztecs, the colonisers 'speak well of the Indians, but with very few exceptions they do not speak to the Indians' (1984, p. 132).

\section{Mass incarceration as disguised violence}

Critics have increasingly recognised mass incarceration as state-organised violence. Many have documented severe and systemic physical and psychological abuses against people who are incarcerated. Some also describe how aggressive incarceration of marginalised populations decimates families and communities. Others analyse how a multi-million-dollar prison industry benefits prison-related industries and gentrification, while bleeding schools and social services (Hamilton, 2015, 2017, Irwin, 2005, Kilgore, 2017, Peláez, 2016). 
Despite the critical analysis, however, U.S. prisons continue to be viewed by many as a mainstay of the U.S. justice system. Multiple factors conceal the brutality of mass incarceration from those of us who remain sheltered from it. A two-tiered system of justice for people of different social classes, the geographic isolation of prisons, prison practices that obstruct communication across prison walls, a mainstream media that tends to cover prison violence only in terms of threats to 'staff security,' and a culture of disdain for people who are less fortunate all contribute to keeping many Americans oblivious to the systemic violence of our criminal-legal system (Davis, 2009, Dole, 2014, Van Cleve 2016, p. xii).

Supporting all these processes of concealment and attitudes of aloofness, I argue, is an imaginary of criminal justice that functions similarly to the colonial imaginary of righteous violence. The ruses of our own institutions are more difficult to discern than those of the past; however, by tracing structural and functional analogies between the colonial imaginary and today's criminaljustice imaginary, I excavate some of the mechanisms that have underpinned widespread indifference to the violence of mass incarceration.

\section{Early expressions of the imaginary of criminal justice}

The images that animate today's imaginary of criminal justice can be traced to classic theories of the modern state. These theories articulate the modern concern with security as well as the identification of security with punishment of lawbreakers. Viewed in historical context, they betray how common notions of 'security' and 'the criminal,' not unlike colonialist myths of 'progress' and 'the Indian,' have been complicit with state-organised violence.

While Spanish, French, Dutch, and English colonisers were invading the Americas, Hobbes and Locke wrote their classic treatises of consent-based government. Notwithstanding their differences, both philosophers describe security as a central purpose of the modern state and both identify security with punishment of lawbreakers. For instance, Hobbes (1968, p. 205) argues that anyone who defies the laws of the state threatens the system of law and 'cannot be received into any Society.' Hobbes (1968, pp. 92, 93) also identifies 'witches' as 'justly punished' for threatening the social order. Locke (1980, p. 12) holds the government to higher standards but he, too, stresses that the government (and, in some cases for Locke, citizens) can punish lawbreakers to safeguard the public and restore justice. As examples of appropriate punishment, Locke explains that someone who has been the victim of a crime that is punishable by death can enslave the alleged criminal, for the accused can always take his own life, if he prefers (1980, p. 17). Locke also allows for a victim of robbery, or even intended robbery, to defend himself by killing the offender, if law enforcement is not immediately on the scene (1980, p. 15). 
In the abstract, the identification of security with punishing lawbreakers has a compelling logic. The images that animated this logic in 17th century England, however, took shape against a background of contested social processes, such that calls for 'security' against 'thieves' lent themselves to being used by the wealthy in their efforts to eliminate people who stood in their way. For instance, as modern capitalism developed, English elite sought to privately enclose community land to pursue more lucrative sheepherding and private industries. This led to the dismantling of feudal and village agriculture, dismissal of farm labourers and retainers, disbanding of feudal armies, and displacement of the people who inhabited common lands (Allen, 1992, Marx, 1967, p. 448). Meanwhile, English law made burglary and minor shoplifting punishable by death. In this context, many of the 'thieves' punishable by execution were people pursuing acts of survival upon being left homeless and unemployed by land enclosures. In addition, 'witchcraft' laws - which led to the torture and execution of over 100,000 people across Western Europe - specifically targeted village women, thereby fragmenting the communities who lived on the common lands and disrupting their resistance to enclosure (Starhawk, 1982). In fact, many of Locke's contemporaries were aware (as a $17^{\text {th }}$-century folk poem put it) that the law locks up the poor but 'leaves the lords and ladies fine/Who take things that are yours and mine' (Anon, n.d.).

\section{The contemporary 'tough-on-crime' imaginary}

In today's world, 'criminal' may seem a fit label for someone who has broken a law; and punishment of criminals may seem a rational means to security. The ruses of colonialism and of Locke's England, however, caution us to consider how today's 'security' and 'criminal' may operate as part of a deceptive social imaginary: an imaginary that obfuscates state violence by inventing depraved subjects against whom violence is cast as 'good for everyone.' I argue below that today's criminal-justice images are, in fact, such cultural inventions.

\section{Myths of 'security'}

The 'security' that drives today's mass incarceration has a specific history. It has roots in early modern identifications of 'security' with punishment of lawbreakers. It also stems from more recent U.S. 'tough-on-crime' rhetoric, which calls for the punishment to be particularly severe. Some scholars trace this tough-on-crime rhetoric to the social unrest of the 1960s and 1970s, when conservatives found it useful to blame the turmoil on 'bad people' (Alexander 2011, pp. 40-43, Irwin, 2005, pp. 229-31). Academics contributed to this outlook by theorising '[w]icked people' who posed a threat to 'innocent people' (James Wilson cited Irwin, 2005, p. 229). In this account, although crime rates did rise in the 1960s, the emerging 'tough on crime' 
rhetoric was a political invention. It called for 'security' against 'wicked people' to promote an agenda of aggressive incarceration that would detract attention from social problems and bring disgruntled social groups under state control.

The call for 'tough-on-crime security' has materialised in specific legal practices. Under the banner of 'tough-on-crime,' states have implemented stiff criminal codes, laws that facilitate police search and seizure, hardline (or non-existent) parole boards, and laws that strip legal rights from people who are incarcerated (Alexander 2011, pp. 61-72, Oleson, 2002, Irwin, 2005, von Wilpert, 2011, Gopnik 2012, Mayeux, 2015, Ghandnoosh, 2017). These practices exhibit 'toughness,' but their security-value rings hollow for many Americans. In fact, studies do not show that aggressive incarceration practices have increased security (Ghandnoosh, 2017, Human Rights Watch., 2007, Wildeman, 2012). Neither do these practices respond to real securityneeds, for they often have corresponded to declining crime rates (Alexander 2011, Peláez, 2016).

Moreover, tough-on-crime practices have made many Americans insecure. For people in low-income neighbourhoods, 'tough-on-crime' has meant greater vulnerability to apprehension by police and abuses after apprehension. For instance, laws that make it easier for police to arrest for 'gang activity' and 'loitering' have led people to be jailed for activities as benign as standing outside with friends or waiting for a bus (Casey \& Watkins, 2014, p. 142, Van Cleve 2016, p. 170). Aggressive pursuit of criminals also has backlogged criminal courts, so that people without bail money can be kept in dangerous jails for extended periods, sometimes years, while they await trial (Gonnerman, 2014). In addition, the increased number of people being prosecuted, with the number of public defenders remaining constant, has meant that indigent people are receiving increasingly inadequate legal counsel. At the same time, recent laws restrict a person's ability to challenge a wrongful conviction, even in the case of clear attorney negligence (von Wilpert, 2011). Additionally, laws that criminalise immigration have exposed many people to racial profiling, detainment, and abuse by instruments of the law simply for 'being brown' (Casey \& Watkins, 2014, pp. 140-144, Rodriguez, 2015, Van Cleve 2016, p. 82).

Within prisons, calls for 'tough-on-crime security' have bred cultures of punishment that expose incarcerated individuals to all kinds of violence. Unrestrained beating, macing, and rape of incarcerated individuals by guards as well as other egregious forms of abuse, including fatal suffocation and submersion in scalding water, have all passed unprosecuted (Oleson, 2002, pp. 854-58, Gonnerman, 2015, Dole, 2016b, Grasha, 2017, Hawkins, 2017, Mills, 2017, Protect 2017). The same cultures of punishment have sanctioned regular 'disciplinary' practices so severe that they constitute torture. For instance, for 'infractions' as minor as 'insolence' or refusing 
sexual advances by guards, guards can send people to solitary units where they spend 23-24 hours per day in a cell of 'gray walls, a solid steel door, no window, no clock, and a light that [is] kept on twenty-four hours a day' (Solitary Watch, n.d, citing resident testimony). For years, or even decades, their only physical contact with another human being 'is the incidental brushing up against the guards who must first place them in handcuffs and chains' before removing them from cells (Solitary Watch, n.d., citing Craig Haney). Another state-sanctioned abuse is the regular use in some states of tactical teams that storm through prisons with clubs and pepper spray, whoop and bang their clubs on bars as they yell at inmates to 'get asshole naked,' keep inmates contained for hours without water or bathrooms while they ransack cells, and commit other unconscionable abuses, such as forcing inmates to march 'nuts-to-butts,' bent over and in close proximity, only partially clothed. Prison officials defend the raids as 'necessary [security] measures' (Dolinar, 2017).

\section{Myths of 'the criminal'}

Like 'security,' America's 'criminal' is also a cultural invention. The narrative that identifies 'security' with harsh punishment also transforms the target of punishment from a person who has broken a law to 'an undifferentiated mass of uncontrollable criminality' (Mayeux, 2015). Multiple cultural practices shore up this fantastical image of 'the criminal' as the embodiment of malignance.

The media, for instance, actively constructs people who are in police custody as despicable beings. A regular feature of television news is the 'perp walk,' in which a person who has been arrested is paraded before media cameras, often in handcuffs and prison attire, thus appearing as an objectified and debased 'criminal' - even before the person has been tried (Dole, 2014, pp. 8-14). The media also distributes mugshots of arrested persons, in which 'the unflattering bright light, the drab background, the name and prisoner ID at the bottom - tells us we are looking at a "criminal,"' an objectified bad guy (Davis 2015). The extent to which America's 'criminal' is a cultural invention is betrayed by the recent trend of Halloween haunted houses that advertise themselves as 'haunted prisons' and offer costumed 'monster-criminals' for Halloween entertainment (Bellware, 2016).

The cultural manufacturing of America's 'criminal' is revealed, also, by its class and race dimensions. As is now well known, African Americans do not use or sell drugs any more than whites; however, African Americans are targeted by police and incarcerated for drugs at much greater rates (Alexander 2011, p. 99). Moreover, as in Locke's time, when the poor were hung for taking a goose off the pasture but lords got away with appropriating entire pastures, 'criminal' applies uniquely to the underclass. As Alexander (2016) puts it, we tolerate the Wall Street executives who destroyed the savings of millions of American families in 2008 and the politicians who 'take millions of dollars from private 
prisons, prison guard unions, pharmaceutical companies, oil companies, tobacco companies, the NRA and Wall Street banks ... killing us softly ... But selling CDs or loose cigarettes? In America, that's treated as a serious crime, especially if you're black.'

Tellingly, when those who fit society's image of 'the criminal' are convicted of crimes, they regularly face decades-long prison-sentences and permanent demonisation (Alexander 2011, pp. 14-177, Davis, 2009, Dole, 2014, pp. 213-22). Yet if upper-class persons are apprehended, their crimes tend to be distinguished as 'white-collar crimes,' for which they receive limited sentences in federal prisons, upon completion of which they are dubbed 'former white-collar criminals.' Some have been invited to speak about business ethics at major universities, where they find understanding and empathy. Walter Pavlo (who served 2 years for a 6 million-dollar fraud scheme) was invited to Temple University because they wanted students to understand how easy it can be to make a mistake that results in prison time' (Farrell \& O'Donnell, 2005). According to the teacher who invited Pavlo, 'The last thing we wanted was finger-wagging, or someone saying, "You better be good people" ... Most people are good, and then they enter an arena with incredibly high pressure' (Terry Halbert cited Farrell \& O'Donnell, 2005). Such empathetic reception has earned Havlo hundreds of thousands of dollars in speaking fees while it has spared affluent people from having to imagine someone like themselves as a 'bad guy.' The attitude that 'most people are good' and environment pressures them to do bad things is not afforded, however, to the many under-privileged people whose brushes with the law have reduced them to 'outcast[s], undeserving of a second chance ... pariah[s] for life' (Dole, 2014, p. 213).

\section{The 'tough-on-crime' imaginary and the institutionalization of state violence}

If today's 'monster-criminal' and 'tough-on-crime-security' are cultural inventions analogous to colonialist myths, then the comparison to colonialism challenges us to consider how these myths have been instrumental in fostering state violence. First, the comparison challenges us to examine how our criminal-justice myths, like colonial myths, contribute to an ensemble of institutional practices that regularise the abuse of people defined as violable subjects. For instance, the myth of 'tough-on-crime-security' has focused legal institutions on punishment and encouraged those institutions to treat people convicted of crimes as mere objects of punishment. In this context, prison employees tend to be trained only in methods of restraint and empowered to punish with little oversight. If long-term solitary confinement and vicious tactical units have become routine, and if physical assaults on incarcerated individuals regularly go unprosecuted, then this is 
because myths of security through punishment of objectified 'criminals' have organised all facets of the criminal-legal system. Tellingly, when the state of California was charged with severe overcrowding and human-rights violations in state prisons, even the state's attorney acknowledged 'very significant violations of constitutional rights' but argued that the main cause of the violations was not overcrowding but 'the culture of disregard for the inmate' (cited in Mayeux 2015).

The comparison to colonialism also highlights how myths of 'the criminal' (not unlike myths of 'the Indian') encourage state officials to treat people who are so labelled as if they were inferior beings, which effectively turns those people into social inferiors. For instance, a study of Chicago's Cook County court system (Van Cleve 2016) describes how judges and lawyers tend to 'criminalise' underprivileged defendants - regardless of their actual relation to the crime in question. The disdain that court professionals held toward people in their custody was clear from the terms they used for them, which included "scum," "pieces of shit," "bad guys" - even "banana suits" (which refers to the jail jumper that defendants in custody must wear in court)' (Van Cleve 2016, p. 57). The most common term for the defendants was 'mopes,' an epithet signifying lack of work-ethic, which translated in court culture to inherent culpability. 'Professionals find it difficult to regard a defendant as anything but a mope,' reports Van Cleve. 'By the professionals' logic, if someone was motivated, hardworking and competent, he or she would not be charged with a crime' (2016, p. 58). Armed with these biases, the courts reduce many of the people in their custody to the stereotypes they hold of them: riffraff to be swiftly processed or abominations to be prosecuted to the fullest extent possible (Van Cleve 2016, pp. 69-73).

When we compare the 'tough-on-crime' imaginary to the colonial imaginary, we likewise challenge ourselves to consider how many of us (like colonial Europeans) have become alienated from the human beings targeted by our myths. The comparison challenges us to consider how we may have detached from incarcerated people in ways that have impaired our own responsiveness to barbarism. For instance, Stateville Correctional Center in Illinois regularly warehouses men for 22-23 hours a day in barren, often sweltering, unventilated, walk-in-closet-sized cells, without even a desk or chair. Meals often consist of spoiled and cockroach-tainted food, are eaten in rooms infected with bird droppings, and are announced over loudspeakers twice a day as a directive to 'line up for feed-time.' And yet, when state inspectors visit, they speak only to the guards about their capacity to control the imprisoned men. They do not speak with the men who are incarcerated or ask them about their treatment as human beings. Similarly, when politicians or students tour prisons, they hear only from prison officials. 'It's like they're visiting a zoo; the prisoners are only there for display' (J. Dole, personal communication, 2 March 2017). 


\section{The criminal-justice imaginary and the silencing of incarcerated voices}

The comparison to colonialism also prompts us to consider how, as in the crushing of indigenous voices under colonialism, our criminal-justice myths facilitate the forceful silencing of incarcerated people. For instance, under the guise of 'security,' many prisons deny journalists access to prisons and some states explicitly prohibit any interviewing of inmates (Gonnerman, 2015). Some states also prohibit incarcerated people from having social-media sites (managed by friends on the outside) where they can post their work (Kelkar, 2017).

In the context of multiple prison rules that obstruct communication across prison walls, incarcerated individuals can express their critical perspectives on prisons only via hunger strikes, work strikes, or buildings taking-overs. Even when incarcerated individuals risk severe punishment by taking such actions, the media tends either to ignore them or reduce their efforts to 'security threats.' For instance, a recent strike against prison labour by thousands of incarcerated individuals across the country received little news coverage (Kim, 2016). At Kinross prison in Michigan, before men went on strike, they attempted to peacefully express their concerns about abusive conditions. The prison responded by punishing those who relayed the grievances. Subsequent peaceful stands of unity by inmates were met with indiscriminate tear-gassing and physical abuse (Thompson, 2017). Another recent strike at Vaughn Correctional Center (known for its severe overcrowding and excessive punitive measures) received media attention when hostages were taken. A rare perspective from inside prison walls reached the public when an anonymous inmate used a stolen phone to explain the strikers' demands: 'education first and foremost,' rehabilitation programs, and accountability for the prison budget; they also were reacting against 'Donald Trump. Everything that he did' (Thompson, 2017, citing anonymous striker). Such perspectives were lost to television news, however, which focused solely on tactics used to crush the strike, the death of a guard, and statements by prison officials promising to punish those responsible. In typical manner, the prison responded with indiscriminate brutality against all men in the facility (Cherry, 2017, Thompson, 2017).

Such drastic responses to prison strikes betray another level of brutality associated with 'tough-on-crime' myths: incarcerated people who share their critical perspectives on incarceration are reduced to 'security threats' and severely punished. As I write, my friend Lacino Hamilton, in response to having shared his views on incarceration in a radio interview, sits in an isolated cell and faces charges that can keep him in lockdown/isolation for years (L. Hamilton, personal communication, 20 September 2017). In response to his political writings, Keven Rashid Johnson was gassed while handcuffed and then left in the gassed cell; he was assaulted with gas again after reporting the incident (Protect Kevin 'Rashid' Johnson from prison 
repression, 2017, Thompson, 2017). Other incarcerated individuals who have worked for prison reform have been physically assaulted and sent to isolation for years or even decades (Blau \& Grinberg, 2016). Human-rights groups report that 'solitary confinement is widely employed against prisoners who are perceived as representing any kind of threat to the absolute power of prison authorities. This is true even if inmates are seeking to organize for positive change and even if they are completely nonviolent' (Ridgeway \& Casella, 2011, citing Solitary Watch). Incarcerated individuals have little opportunity to challenge such charges, because the charges 'are levied, adjudicated, and enforced by prison officials with little or no outside oversight' (Solitary Watch, n.d.).

In circular fashion, the repression of incarcerated people's voices has helped maintain the myth that incarcerated people have nothing worthwhile to say. It has allowed systemic inattention to incarcerated individuals to pass unnoticed..

The silencing of incarcerated voices likewise has prevented many of us from seeing the human beings beneath the 'criminal' label. It has prevented us from seeing that the targets of aggressive incarceration have been largely people with mental illnesses, young adults whose only family have been gangs and in whom the state has had no interest until charging them with crimes, people of low socio-economic status who have been targeted by police and who lack adequate legal representation, and even people like the displaced of Locke's era who have been apprehended by the state in order to make way for economic ventures of the wealthy (Alexander 2011, pp. 97-139; Castro,2015, Dole, 2014, pp. 19-93, Hamilton, 2015, 2017, Van Cleve 2016, von Wilpert, 2011). The repression of incarcerated voices also has denied recognition to the many individuals who have educated themselves while in prison, worked hard to improve their lives, and are "looking to get back some self-worth by somehow giving back" (Dole, 2004) 2017b, 2015

\section{Conclusions: the need for resistant imagination}

Finally, a comparison of today's criminal-justice imaginary to the colonial imaginary directs us to consider how the criminal-justice imaginary has thwarted the imaginative work necessary for those of us outside of prison to understand mass incarceration. Arendt has explained how imaginative 'visiting' of other people's standpoints is essential to understand political phenomena. Feminist standpoint theorists have underscored the need to 'visit,' in particular, the standpoint from marginalised lives, for such standpoints offer unique insight into social contradictions that ruling beliefs obscure (Stone-Mediatore, 2003, pp. 162, 179-184). In the case of contemporary mass incarceration, however, incarcerated people have been so thoroughly demonised that the missing perspective is hardly noticed. In 
addition, the brutal silencing of incarcerated people who attempt to express their political views has reinforced the myth that incarcerated people have no views beyond those projected onto them. 'Tough-on-crime' myths even encourage self-satisfaction in our indifference to the targets of our 'toughness.' 'Criminals,' says Alexander (2011, p. 141), 'are the one social group in America we have permission to hate.'

If edifying myths and brutal reinforcement of those myths have treated incarcerated people as voiceless and violable subjects, then the comparison to colonialism also challenges us to reexamine our most deeply ingrained notions of 'violable subject.' It challenges us to consider the perspective of the people we have presumed to have no perspective. For those of us outside of prison, imagining the perspective of people locked within prisons is no simple task. As feminist critics warn, imagining the perspective of people in situations radically different than our own demands arduous practical work as well as openness to the unsettling of familiar narratives. In this case, it means destabilising the divisions between 'good' and 'bad' people, and between law and violence, around which many of us have oriented our lives. It also demands endeavours such as close engagement with the work of incarcerated writers and artists, reaching out through letters to incarcerated individuals, or joining practical struggles with incarcerated people or their families.

Fortunately, various journals, websites, and prison-justice organisations facilitate such endeavors by sharing the work of incarcerated writers, artists and activists. The stories shared through these forums help make palpable the monstrosities of U.S. prisons as well as the resilient humanity of the individuals confined within them. For instance, in his story of the animals he encounters while serving a life-sentence, Joseph Dole highlights the irony of being labelled an 'animal' by a society that 'misunderstands both incarcerated people and animals' (2017c, p. 143). His story invites us into a world where 'yard time' means being locked into a solitary concrete box; 'violent criminals' nurture a baby turtle; 'jailbirds' connect with 'the free world' by exchanging chirps with real birds; and 'one of society's alleged bogeymen' risks punishment to help a baby bird return to its mother (Dole, 2017c, pp. 132-138). When Dole recounts the guards threatening him as he gently coaches a frail bird to safety; and when he describes 'clanking along in shackles, a waist chain, and handcuffs encased in a black, steel padlocked box,' while to his amazement 'a large rabbit jumped out of the hedges along the path, and passed right between [his] legs, brushing the shackles' (2017c, p. 140), the images confound familiar narratives of 'human' and 'animal,' 'good guy' and 'criminal.' They guide us in imagining the unimaginable: the caging of human beings. When Dole proposes that his fellow Americans 'stop painting us all with a broad stigmatizing brush' and 'start acting more like the animals in here,' who judge the incarcerated men as individuals, he 
provokes a new look not only at incarcerated people but at ourselves as jailers, who keep 'hundreds of thousands of people incarcerated for life, long past the time they cease posing any threat to society' (2017c, p. 143).

Although fraught with challenges, the task of engaging the voices and imagining the perspective of people who are incarcerated is vital to undermining the mechanisms of institutionalised violence. We can respond 'to people who say "prison shouldn't be a picnic,"' says Hamilton (2015), only when we 'shift conceptions of the humanity of the incarcerated' and begin to face incarcerated people as human beings. Documentation of the myriad abuses of human dignity and bodily integrity that are systemic to U.S. prisons is also crucial; however, if the abuses are not to be refashioned into ruses of 'just punishment' and 'necessary security measures,' then we need to begin viewing these phenomena from the standpoint of people who are incarcerated.

I cannot anticipate all the ways that the standpoint of the incarcerated would illuminate the U.S. criminal-legal system. Based on my analysis, however, I anticipate that such endeavours would raise troubling questions. For instance: How can we distinguish between law and violence when routine legal practices violate human integrity? How does the systematic disregard for the voices and humanity of incarcerated individuals degrade our own humanity? And how can we heal our communities and secure all members of our society from violence? Careful engagement with incarcerated voices and imagination of their perspective does not provide easy answers. Nor does it directly confront the extreme power imbalances that facilitate violence against incarcerated people. Still, by raising such questions and encouraging us to approach them with a sense of connection to the lives from which many of us have been alienated, the diligent 'visiting' of incarcerated standpoints could help us resist some of the mechanisms of institutionalised violence and reckon more honestly with that violence.

\section{Note}

1. In this paper, I use the first-person plural to refer to people who have not been incarcerated. I hope that my readers will include people on both sides of prison bars; however, my argument about the need to imagine the standpoint from incarcerated lives is directed to people who lack first-hand experience of incarceration.

\section{Acknowledgments}

I am grateful to the two anonymous reviewers, Mihaela Mihai, John Stone-Mediatore, Debbie Stone Bruell, and Joseph Dole for illuminating feedback on earlier versions of this paper. 


\section{Disclosure statement}

No potential conflict of interest was reported by the author.

\section{Notes on contributor}

Shari Stone-Mediatore is Professor of Philosophy at Ohio Wesleyan University. She is the author of Reading Across Borders: Storytelling and Knowledges of Resistance as well as various articles and book chapters in the politics of knowledge, feminist theory, and institutionalized violence.

\section{References}

ACLU. (2011). Abuse of the human rights of prisoners in the United States. Submission to the United Nations Human Rights Commission 16th session on solitary confinement [online]. Retrieved March 10, 2017, from https://www.aclu. org/files/assets/ACLU_Submission_to_HRC_16th_Session_on_Solitary_ Confinement.pdf

Alexander, M. (2011). The new Jim Crow: Mass incarceration in the age of colorblindness. New York: The New Press.

Alexander, M. (2016, July 9). Following horrific violence, something more is required of us. Moyers \& company [online]. Retrieved March 10, 2017, from http://bill moyers.com/story/following-horrific-violence-something-required-us/

Allen, R. C. (1992). Enclosure and the yeoman. New York: Clarendon Press.

Anon., (n.d.). The goose and the common. Retrieved February 16, 2017, from http:// unionsong.com/u765.html

Arendt, H. (1953a). A reply. A Review of Politics, 15, 76-85.

Arendt, H. (1953b). Understanding and politics. Partisan Review, 20, 377-382.

Arendt, H. (1958). The human condition. Chicago: University of Chicago.

Arendt, H. (1982). Lectures on Kant's political philosophy. Chicago: University of Illinois Press.

Bellware, K. (2016, October 31). Many people already see prisoners as monsters. Do 'haunted prisons' make it worse? Huffington post [online]. Retrieved March 10, 2017, from http://www.huffingtonpost.com/entry/haunted-prisons-halloween_us_ 58173d9de4b0990edc320e42

Blau, B., \& Grinberg, E. (2016, October 31). Why U.S. prisons launched a nationwide strike. CNN U.S. edition, [online]. Retrieved March 9, 2017, from http://www.cnn. com/2016/10/30/us/us-prisoner-strike/

Casey, E., \& Watkins, M. (2014). Up against the wall: Re-imagining the U.S.-Mexico border. Austin: University of Texas Press.

Castro, F. (2015, March 5). Gangs of the state. The Hampton Institute [online]. Retrieved August 14, 2017, from. http://www.hamptoninstitution.org/gangs-ofthe-state.html\#.WZMQPFWGOUk

https://www.thenation.com/article/prison-education-reduces-recidivism-by-over -40-percent-why-arent-we-funding-more-of-it/

Cherry, A. (2017, April 18). Behind the walls. WDEL [online]. Retrieved August 14, 2017, from http://www.wdel.com/news/video-behind-the-walls-letters-fromsmyrna-s-vaughn-inmates/article_a4b63686-23b8-11 e7-922b-57d75356615e. html 
Davis, A. (2009). Arbitrary justice. Oxford: Oxford University Press.

Davis, C. (2015, February 4). Against mugshots Truthout [online]. Retrieved March 9, 2017, from http://www.truth-out.org/news/item/28903-against-mugshots-photosof-the-state-s-latest-catch-don-t-belong-in-a-free-press

Dilts, A. (2014). Punishment and inclusion: Race, membership, and the limits of American liberalism. Fordham: Fordham University Press.

Dole, J. (2014). A costly American hatred. Berryville, AR: Midnight Express Books. http://www.truth-out.org/opinion/item/36940-abolish-long-term-solitaryconfinement-it-s-a-threat-to-the-public

http://minutesbeforesix.blogspot.com/2016/11/indefinite-dicipline.html http://www.truth-out.org/opinion/item/40853-a-plea-from-inside-prisons-mustoffer-college-classes

$\lambda$

Dole, J. (2017). Yard time with the animals. Columbia Journal, 55, 132-143.

Dolinar, B. (2017, January 2). Truthout [online]. Accessed March 10, 2017, from http://www. truth-out.org/news/item/38941-orange-crush-the-rise-of-tactical-teams-in-prison

Dussel, E. (1995). The invention of the Americas. (M. Barber, Trans). New York: Continuum.

Everest, L. (2013, July 7). Interview with Carol Strickman. Prisoners' struggle against 'cruel and unusual punishment amounting to torture. Revolution newspaper [online]. Retrieved March 7, 2017, from http://www.revcom.us/a/309/interviewwith-Carol-Strickman-en.html

Fanon, F. (1967). Toward the African revolution. (H. Chevalier, Trans). New York: Grove Press.

Farrell, G. \& O'Donnell, J., (2005, November 15). Ethics training as taught by ex-cons. USA Today [online]. Retrieved February 25, 2017, from http://usatoday30.usatoday. com/money/companies/management/2005-11-15-ethics-cov-usat_x.htm

Ghandnoosh, N. (2017, January 31). Delaying a second chance. The sentencing project [online]. Retrieved March 9, 2017, from http://www.sentencingproject.org/publica tions/delaying-second-chance-declining-prospects-parole-life-sentences/

Gonnerman, J. (2014, October 6). Before the law. The New Yorker [online]. Retrieved March 20, 2017, from http://www.newyorker.com/magazine/2014/10/06/before-the-law

Gonnerman, J. (2015, September 10). Prisoners' lives matter. The New Yorker [online]. Retrieved February 22, 2017, from http://www.newyorker.com/news/news-desk /prisoners-lives-matter

Gopnik, A. (2012, January 30). The caging of America. The New Yorker [online]. Retrieved March 9, 2017, from http://www.newyorker.com/magazine/2012/01/30/ the-caging-of-america

Grasha, K. (2017, January 30). Woman alleges rape by Warren County jail officers. Cinncinati [online]. Retrieved March 9, 2017, from http://www.cincinnati.com/ story/news/2017/01/30/woman-alleges-rape-warren-county-jail-officers-lawsuit /97259510/

Hamilton, L. (2015, June 23). Understanding the human cost of imprisonment. Truthout [online]. Retrieved August 14, 2017, from http://www.truth-out.org/ news/item/31406-understanding-the-human-cost-of-imprisonment

Hamilton, L. (2017, April 30). The gentrification-to-prison pipeline. Truthout [online]. Retrieved August 14, 2017, from http://www.truth-out.org/news/item/40413-thegentrification-to-prison-pipeline

Hawkins, D. (2017, March 20). An inmate died after being locked in a scalding shower for 2 hours. His guards won't be charged. The Washington Post [online]. Retrieved 
August 14, 2017, from https://www.washingtonpost.com/news/morning-mix/wp/ 2017/03/20/an-inmate-died-after-being-locked-in-a-scalding-shower-for-twohours-his-guards-wont-be-charged/?utm_term $=.685518569028$

Hegel, G. W. (1956). The philosophy of history. (J. Sibree, Trans). Mineola, NY: Dover. Hobbes, T. (1968). The leviathan. New York: Penguin Books.

Human Rights Watch. (2007). No easy answers. Human Rights Watch Report [online]. Retrieved March 9, 2017, from https://www.hrw.org/report/2007/09/11/no-easyanswers/sex-offender-laws-us

Irwin, J. (2005). The warehouse prison. Oxford: Oxford University Press.

Kelkar, K. (2017, January 29). Resistance builds against social media bans in Texas prisons. PBS news hour [online]. Retrieved March 5, 2017, from http://www.pbs. org/newshour/updates/social-media-ban-texas-prisons/

Kilgore, J. (2017, February 28). Mass incarceration in the cornfields. Truthout [online]. Retrieved March 29, 2017, from http://www.truth-out.org/news/item/39651-massincarceration-in-the-cornfields-shattered-families-and-racial-profiling-in-smalltown-america

Kim, T. (2016, October 3). A national strike against 'prison slavery'. The New Yorker [online]. Retrieved March 5, 2017, from http://www.newyorker.com/news/newsdesk/a-national-strike-against-prison-slavery

Locke, J. (1980). Second treatise of government. Indianapolis: Hackett.

Marx, K. (1967). The German ideology. In L. Eason \& K. Guddat (Eds.), Writings of the young Marx. Garden City: Doubleday, 403-473.

Mayeux, S. (2015, March 22). The unconstitutional horrors of prison overcrowding. Newsweek [online]. Retrieved March 10, 2017, from http://www.newsweek.com/ unconstitutional-horrors-prison-overcrowding-315640

Mignolo, W. (2005). The idea of Latin America. Malden, MA: Blackwell.

Mills, S. (2017, July 17). How did Terrance Jenkins die? The Chicago Tribune [online]. Retrieved September 30, 2017, from http://www.chicagotribune.com/news/local/ breaking/ct-pontiac-inmate-death-20170717-story.html

Oleson, J. C. (2002). The punitive coma. California Law Review, 90(3), 829-902.

Ortega, M. (2006). Being lovingly, knowingly ignorant. Hypatia, 21, 56-74.

Peláez, V. (2016, August 28). The prison industry in the United States: Big business or a new form of slavery? Global Reach [online]. Retrieved July 15, 2017, from http:// www.globalresearch.ca/the-prison-industry-in-the-united-states-big-business-or -a-new-form-of-slavery/8289

Protect Kevin 'Rashid' Johnson from prison repression. (2017, January 19). Block report radio [online]. Retrieved March 10, 2017, from http://www.blockreportra dio.com/index.php/news2/item/407-protect-kevin-rashid-johnson-from-prisonrepression

Quijano, A. (2000). Coloniality of power, Eurocentrism and Latin America. Nepantla: Views from the South, 1(3), 533-580.

Ridgeway, J., \& Casella, J. (2011, June 17). Confronting torture in U.S. Prisons. Solitary Watch [online]. Retrieved August 14, 2017, from http://solitarywatch.com/2011/06/ 17/confronting-torture-in-u-s-prisons-a-qa-with-solitary-watch/

Rodriguez, R. (2014). Our sacred maíz is our mother: Indigeneity and belonging in the Americas. Tucson: University of Arizona Press.

Rodriguez, R., 2015. 'Not Counting Mexicans or Indians': The many tentacles of state violence against Black-Brown-Indigenous communities [online]. Retrieved March 9, 2017, from http://www.truth-out.org/news/item/28921-not-counting-mexicans-or- 
indians-the-many-tentacles-of-state-violence-against-black-brown-indigenouscommunities

Rovner, J. (2016, July 1). Juvenile life without parole: An overview. The sentencing project [online]. Retrieved March 9 2017, from http://www.sentencingproject.org/ publications/juvenile-life-without-parole/

Smith, A. (2005). Conquest: Sexual violence and American Indian genocide. Cambridge: South End Press.

Solitary Watch. FAQ, (n.d.), [online]. Retrieved March 10, 2017, from http://solitary watch.com/facts/faq/

Starhawk. (1982). Dreaming the dark. Boston: Beacon Press.

Stone-Mediatore, S. (2003). Reading across borders: Storytelling and knowledges of resistance. New York: Palgrave Macmillan.

Taylor, C. (1993). Positioning subjects and objects: Agency, narration, relationality. Hypatia, 8(1), 55-80.

Thompson, H. (2017, February 17). What happened at Vaughn prison? Jacobin [online]. Retrieved February 27, 2017, from https://www.jacobinmag.com/2017/ 02/vaughn-prison-hostage-attica-uprising/

Todorov, T. (1984). The conquest of America: The question of the other. New York: Harper \& Row.

von Wilpert, M. (2011). Holland v. Florida: A prisoner's last chance, attorney errors, and the antiterrorism and effective death penalty act's one-year statute of limitations period for federal habeas corpus review. Fordham Law Review, 79, 1429-1476.

Wildeman, C. (2012, April 24). Mass incarceration. Oxford bibliographies [online]. Retrieved March 10, 2017, from http://www.oxfordbibliographies.com/view/docu ment/obo-9780195396607/obo-9780195396607-0033.xml 